\title{
The effectiveness of e-learning: Based on students' evaluation
}

\author{
Rudaleva Irina $^{1}$, Kabasheva Irina ${ }^{1 \mathrm{a}}$ and Kovaleva Elvina ${ }^{2}$ \\ ${ }^{1}$ Kazan Federal (Volga region) University, 38 Kremlevskaya St. Kazan, 420008, Russia \\ ${ }^{2}$ Institute of economcs, management and lov, 42 Moskovskaya St. Kazan, 420111, Russia
}

\begin{abstract}
There was a survey done on the effectiveness of distance learning based on electronic educational resources of Kazan Federal University (KFU). The survey showed the attitude of the students to practical use of distance learning which came out as neutrally-positive. Most students evaluate distance learning at KFU as effective. Economic analysis showed that significant factors in the effectiveness are: timeliness of E-Learning appearance at the university, interface of Electronic Educational Resources (EER) system on the university website; constant use of E-Learning elements by teachers in the process of education; evaluating the necessity of use of E-learning elements at the university; availability of video connection with the teacher as an E-learning element.
\end{abstract}

\section{Introduction}

High science-technology development, changes in economic, social and other spheres of human lives put new demands to human capital, encouraging people to develop intellectually, personally and professionally. Socially-economic progress in social life brings out the great desire in a person to achieve maximum results and perfect himself even more, than the presence of certain qualification, knowledge and skills. These conditions determine actualization and demand in a professional non-stop training in a worker who gets a chance to constantly perfect his professionalism.

We can distinctly see the development of this statement according to the UNESCO reports which make the statement «learn your entire life» a priority in a nowadays educational policy [the pilot project of IITE UNESCO, 2012]. The idea of ongoing education finds itself in applying the distance learning, that probably got its name due to "flexibility" of a chosen place, time and sometimes pace of learning [1]. With the help of internet and other virtual means students get opportunity to overcome distance and time difficulties without being apart from their life process and get their first and second higher (college/university) education as well as additional training.

\footnotetext{
${ }^{a}$ Corresponding author: kaba.73@mail.ru
} 
Thus, availability of this form of education makes it more and more popular each year. We think we can agree with some scientists' opinion on the degree and level of readiness to learn distantly in each particular individual. We mean "...not only availability of learning materials and computer skills, but also skills of working independently" [2].

Not only effectiveness of using electronic educational resources in higher education is debatable, but understanding their essence is debatable as well. There are at least two main essences of electronic educational resources, according to the scientific books and practical pedagogical activity of university professors. First we understand "electronic resource": «.....an electronic educational resource is any kind of informational product that can be reproduced by a computer $»[3]$.

The foundation of the second direction of EER (Electronic Educational Resources) is educational materials on the computer which is a complex phenomenon. For instance, Telegin A. A. thinks that electronic educational resources is a whole system of orderly set educational materials in the form of texts, graph, audio and video files etc. It assumes that the information is actively absorbed by students forming in them knowledge and practical skills in a specific area of science [4].

To our opinion both ways have their right to exist, the differences is that in the first case the definition of EER comes from its purpose which is the source of educational materials for auditory and self-study, whereas the second case defines it as a way of providing information (computer technology).

The perspectives of having higher education in a hybrid form (both traditional and electronic) or fully electronic rises a logical question, whether this process is of quality and effectiveness. Evaluating quality of electronic education is necessary for innovations and improvement in the educational process. There are researches around the world that not only measure development and functioning of programs but also measure efficiency and quality of electronic education. For example, E-xcellence program offers a set of 33 benchmarks of quality covering institutional, pedagogical, technical, ethical and organizational aspects of electronic education. These aspects cover management (institutional and program levels), products (study program, development and delivery of the course) and services (students support, science and pedagogics workers support and staff support) [5].

Quality and effectiveness of education can be characterized with the help of three index groups: the quality of educational content, the quality of educational technologies, and the quality of the results of education. To develop criteria for effectiveness and quality of electronic education we need to distinguish the factors that provide the required quality in education. Indicators of evaluation of the quality in electronic education are not only an addition to already existing quality evaluation systems, but also an optimizer of study process which overall guarantees high level of education [6].

Voitovich I. K. suggests to distinguish the four groups of indicators that evaluate the quality of effectiveness of electronic education: content indicators, different forms of electronic teaching indicators, infrastructure and university electronic environment indicators, didactics and technology of electronic education indicators. All applied to students. Without going into certain indicators analyses, applying new informational technologies at a school improves the teacher-student interaction, develops cooperation and interaction between students themselves, stimulates active learning, increases motivation, supports different styles of education and gives an opportunity to work with the educational material at the most convenient time [7].

It is interesting to see the survey of Borodina T.F., where teachers evaluate factors that lead to reduction of effectiveness of electronic courses: inadequate level of computer skills and lack of specialized help, inadequate use of all the EER, inconsistency of EER applied to a particular course or a student group, abuse of EER, lack of time while developing the 
EER, psychological barriers in teachers and lack of readiness in students to work with EER, also lack of equipment. Thus Borodina T. F. makes the conclusion that effectiveness of EER changes as the usage increases: the more a teacher uses EER the more effective EER gets [8]. We think these results are not far from reality because as EER is being practically used, teachers master the ability to apply EER as well as correcting EER according to individual needs, sorting the material and comparing its content.

The federal project «Monitoring EER» published the results of the survey on effectiveness of EER. Based on these results EER promotes increased interest to the subject in students, grasping the material better, getting extra tasks on the subject, increasing the quality of education, individualization of the educational process. With all that $66.6 \%$ of the teachers noted that students' interest for the given subject increased, the material was absorbed $56.1 \%$ better, opportunities of getting extra material on the subject rose $45.6 \%$ more, quality of education increased by $28.3 \%$, educational process became $23.2 \%$ more individualized [9].

There, education is viewed from the perspective of systematic knowledge gotten from EER content and their performance whereas satisfaction in education was analyzed based on adaptation technology Model (TAM) reception. The research results turned out to be very perspective as far as increasing the efficiency of electronic education systems: no gender, no school system affect students satisfaction in electronic education. At the same time they analyzed the effect of the three forms of education on the results on educational process. They are the traditional form, the fully online form, and the mixed form. Their conclusion was that mixed groups combined with online form give the highest educational results [10].

A group of scientists with Awadh A.Y., Al-Qahtani and S.E. Higgins did a similar research and viewed influence of electronic education, mixed education and traditional education in a classroom setting on the students' educational results. The results showed that there was a statistically significant difference between the three educational methods as far as students' achievements go and the mixed method wins. With all that there weren't found any significant differences between electronic and traditional methods of education in terms of showing more results in learning [11].

Scientists Hassan M. Selim Ahmed studied the effectiveness of using tools and ELearning technologies as an addition to regular courses in high schools in order to increase the quality of education for students [12]. This research evaluated perception of the hybrid form of education by students, and particularly the factors that affect teir satisfaction with the process of studying. Students were offered to evaluate the hybrid electronic form of education based on three critical factors: characteristics, infrastructure of information technology and technical support of the process. The results showed significant influence of all of the three factors when accepting hybrid electronic courses. Simultaneously two of the last factors come as key factors in increasing the results and making hybrid forms of education successful.

Kihyun Kim, Silvana Trimi, Hyesung Park, Shanggeun Rhee researched the mostly wide spread platform of electronic education Course Management Systems (CMSS) from the point of satisfaction and special offers for the users [13]. They did this study based on the following basic factors: quality of the system, quality of the information, quality of learning, satisfaction of users, and profit. The results showed that quality of the system and of information, as well as quality of learning influence the users positively and satisfy them, which increases advantages of electronic educational courses.

According to E. King and R. Boyatt the use of electronic education in high schools is used as a supportive tool in their curriculum [14]. Based on that, they did factor analysis of its influence on the results of the educational process. The factors that were distinguished by the scientists as influential to the effectiveness of electronic education are the following: 
institutional infrastructure, teachers' attitude and skills, expectations of students. The results showed the importance of institutional strategy directed to providing enough information and finances as well as providing guidance to increase the effectiveness of electronic education. At the same time scientists noticed the necessity to support institutional strategy by various programs that help develop the teachers' staff and give opportunities to exchange experience among colleagues.

Thus, there is the promising of electronic resources usage in teaching and increasing the staff qualification and skills. Especially, due to wide use of electronic forms of education for intra-corporate investments of business entities [15]. In the review by K. Anderson in 2011 growth of intra-corporate investments into developing projects reached $50 \%$ from the year 2010 level. Based on the research, the majority of companies chose building performance management systems among main streams of investment in L\&D field, experimenting in the sphere of training stimulators development, mobile and distance learning, and also in team work tools for territorially remote workers and virtual team members.

From the interview with the leaders of developing projects in top Russian companies we see that in $2010 \mathrm{y}$. MTS spent 83.000 hours for staff training, out of those 43.000 hours they used for traditional daily training and 40.000 hours for distance learning. Companies are enlarging the number of distance learning courses and invite teachers and experts more and more to create an environment where they would have teachers and trainers of their own [16].

At the same time there are key problems that decrease the effectiveness and realization for projects of electronic education in Russian companies. Among them, firstly the fact that their focus is only on traditional distance learning in the "Electronic course plus test" format. Especially in mass learning groups where students can interact with each other which lead to incorrectness of their results. For the results of distance learning to be objective, it is recommended to add to individual/group projects security in webinar format or full-time validation. In other words, to move from the old ways to mixed education or blended learning that dominates nowadays. Also update tests on the regular basis so to stop losing of the top information into open sources.

Secondly, there is a problem of result forgery in distance learning due to: difficulty of user identification, especially if employees of the same company work in the same room and can switch places at their computers. So for those who desire to acquire objective results of final tests it is a question how and where to hold them. Maybe a special accommodation provided with video cameras and other equipment or observers present is needed in order to be able to control the process [17].

In any case today the world HR-community definitely gives its preferences to blended learning [18], that allows us to use strong sides of full-time educational forms as well as various online and offline tools (webinars, video conferences, etc). That way, students can be flexible planning their tasks and chose the most suitable time in the given curriculum. We need to notice that in business sphere this is extremely important. According to survey for $90 \%$ of distance learning students of Moscow Business School this very parameter is one of the key ones.

\section{Method}

We studied the effectiveness of using electronic educational resources as a mean of distance learning in Kazan Federal University (KFU). For that a questionnaire was made consisting of 19 questions. 100 different year students were asked, they were 33 masters' students, 33 bachelor graduates, 34 first, second and third year students. 
As a variable a question was chosen: Evaluate effectiveness of distance learning based on EER at KFU with a 5 point scale, where 1 is the lowest (unnecessary system) and 5 is the highest (EER can fully give the necessary database for students). AS a result the following information was obtained concerning the most significant factors:

- Timeliness of EER appearance at the university;

- Condition and EER system interface on the university website;

- Use of EER system by the teacher during educational process;

- Evaluation of the necessity of EER system at the university;

- Availability of video connection with the teacher while using EER.

\section{Findings}

In the Table 1 you can see the received model parameters. In the received model all factors turned to be significant in $\mathrm{P}$ criteria, which should be equal to 0.05 or less. The created model is relatively qualitative. The coefficient of determination (R-square $=0,580$ ) shows that $58 \%$ of variance dependent variable is formed with the influence of listed in the model factors. In the received model P made 2,17-16, which shows high quality of the model. The degree of reliability is $99 \%$. The White test showed that there is no heteroskedasticity.

\begin{tabular}{cccccc}
\multicolumn{6}{c}{ Table1. Model MNC of the effectiveness of distance learning system use (100 observations were used $)$} \\
\hline Variable & $\begin{array}{c}\text { Coefficie } \\
\text { nts }\end{array}$ & $\begin{array}{c}\text { Common } \\
\text { mistake }\end{array}$ & t-statistics & $\begin{array}{c}\text { P- } \\
\text { parameter }\end{array}$ & \\
\hline const & $-0,17987$ & 0,365704 & $-0,4918$ & 0,62398 & \\
$x_{1}$ & 0,209201 & 0,0809687 & 2,5837 & 0,01131 & $* *$ \\
$x_{2}$ & 0,278142 & 0,0733623 & 3,7913 & 0,00026 & $* * *$ \\
$x_{3}$ & $-0,15977$ & 0,0676185 & $-2,3628$ & 0,02020 & $* *$ \\
$x_{4}$ & 0,444615 & 0,0650232 & 6,8378 & $<0,00001$ & $* * *$ \\
$x_{5}$ & 0,154141 & 0,059161 & 2,6054 & 0,01067 & $* *$ \\
\hline
\end{tabular}

Test: $\mathrm{LM}=24,4356$.

p-variable $=\mathrm{P}($ Хи-square $(20)>242,4356)=0,223882$.

The analysis of the model for multicollinearity showed its absence.

AS a result the following regression equation was received:

The correlation coefficients (chart 2) showed that the most influential onto the effective use of EER is $\mathrm{X}_{5}$ factor- availability of video connection with the teacher.

\begin{tabular}{cc} 
Table 2. The correlation matrix & \\
\hline $\mathrm{Y}$ & $\mathrm{X}$ \\
\hline 0,4943 & $\mathrm{X}_{1}$ \\
0,4029 & $\mathrm{X}_{2}$ \\
0,0538 & $\mathrm{X}_{3}$ \\
0,6534 & $\mathrm{X}_{4}$ \\
0,2370 & $\mathrm{X}_{5}$ \\
1,000 & $\mathrm{Y}$ \\
\hline
\end{tabular}




\section{Conclusion}

The research showed the overall neutrally-positive attitude of students. Use of EER by students is periodic. Nevertheless the third of the respondents think that implementation of EER into learning process is timely and necessary.

The existing interface, portal design www.e.kpfu.ru and areas are evaluated as decent enough and at a comfortable work level.

According to the students, teachers actively (above average) use EER in the educational process. The vast majority of students think it is necessary to have video connection with the teacher. Presently the university distance learning center isn't able to provide it. Video connection such as Skype, Viber are used by some teachers, but it's their personal decision.

The most actively used elements of EER are tests and homework. 2/3 of the interviewed students think it is effective to use EER in educational process. Although more students think they have low motivation for working with EER. Besides that the reason for low effectiveness of distance learning is mentality, lack of trust of potential users to educational services, low level of assimilation of material by students, lack of control or defective control from the teachers.

So, we can view distance learning methods, according to the interviewed students as effective, necessary, still additional elements of educational process at the university.

Guidance in using the pilot project of IITE UNESCO Learning For Future (LFF). IITE UNESCI. (2012). February, $29 p$.

\section{References}

1. Andreev, A., Educative basics of distance learning. M., RAO, 213p (1999)

2. Kalinina, A., I. Distance learning as a past of ongoing educational system and the role of self-education in a distance learning. Almanac of Moscow University. Pedagogical education, Vol.1, p.100-105 (2014)

3. Osetrova, N., A book and electronic means in education. M., 144p (2003)

4. Telegin, A., Perfecting methodical system in teachers' education and development educational electronic resources in computer studies: Ph.D in pedagogics. - Kursk, 23p (2006)

5. Tsarkov, E., E-xcellence - a manual on quality electronic education in high schools.URL:http://technical.bmstu.ru/LTEP/Events/PetrSU_2009/Tsarkov_E_xcellen ce.pdf (2009)

6. Kuznetsov, I., Evaluating the quality of distance learning. Internet magazine «Science study», Vol. 2 (7). URL: http://naukovedenie.ru/index.php?id=164 (2011)

7. Voitovich, I., Criteria of effectiveness of electronic education and of quality of electronic educational programs in high schools Almanac of TSPU (Tatarstan State Pedagogical University)V ol. 4 (145), p.152-156 (2014)

8. Borodina, T., Application of electronic educational resources in the educational process of high school and determination of their effectiveness. Young scientist, Vol.13 (2014)

9. EER monitoring [Electronic source]. — is available at: http://eor-np.ru/node/55.

10. Lee, L.-T., Hung, J., Effects of blended e-Learning: a case study in higher education tax learning setting. Human-centric Computing and Information Sciences, Volume 5, pp.15 (2015)

11. Awadh, A.Y. Al-Qahtani \& Higgins, E., Effects of traditional, blended and e-learning on students' achievement in higher education. Journal of computer assisted learning, Volume 29, Issue 3, pp. 220-234 (2013) 
12. Hassan, M. Selim Ahmed, Hybrid E-Learning Acceptance Model: Learner Perceptions. Decision Sciences Journal of Innovative Education .Volume 8, Issue 2, pp. 313-346 (2010)

13. Kihyun, K., Silvana, T., Hyesung, P., Shanggeun, R., The Impact of CMS Quality on the Outcomes of E-learning Systems in Higher Education: An Empirical Study. Decision Sciences Journal of Innovative Education Volume 10, Issue 4, pp. 575-587 (2012)

14. King, E., Boyatt, R., Exploring factors that influence adoption of e-learning within higher education British Journal of Educational Technology (2014)

15. Anderson, K., The road to recovery. http://clomedia.com/articles/view/the-road-torecovery (2011)

16. Podtserob, M., Don't waist. Vedomosti. Vol.83 (2849) (2011)

17. Astakhova, T., Possibilities and problems of distance learning forms, selection of distance learning system. Management of human potential, № 01 (29), pp.56-63 (2012)

18. Mosher, B., Real world survival. — http://clomedia.com/articles/view/4598 (2011) 